\title{
Sandra Stotsky Needs No Defense, Her Ideas Do
}

\author{
James V. Shuls
}

Strawmen are easy to defeat. You simply build up a position that isn't so, and then proceed to demolish that argument all the while failing to address the real issue at hand. This is exactly what Richard Phelps does in his piece, "In Defense of Sandra Stotsky.” He starts by singing the praises of Stotsky, who was an integral part of the reforms that shaped the Massachusetts education system in the 1990s. Then Phelps explains how Stotsky became a stalwart against the Common Core as she eschewed opportunities to compromise principles. Phelps then sets up his dismissal of me: "Not conforming, however, appears to have made her some enemies." The strawman was built-Shuls opposes Stotsky because of her principled positions on Common Core and other reforms-and then Phelps knocks it down.

Let's dismiss this farce. My criticism of Stotsky has nothing to do with Common Core, or her dogged insistence on rigorous curricula and high standards for teachers. I am on the record opposing Common Core and have even testified as such in the Missouri state legislature. My criticism in my essay was focused entirely on her book and the terrible ideas presented therein. Phelps offers a compelling defense of the credentials of Sandra Stotsky; but Stotsky needs no defense-her ideas do.

I was asked by $A Q$ to write a review essay of Stotsky's 2018 book, Changing the Course of Failure: How Schools and Parents Can Help Low-Achieving Students, and Eva Moskowitz's The Education of Eva Moskowitz: A Memoir (2018). In that essay, “A Dangerous Belief” (Fall 2019), I highlight the stark contrast between Stotsky's and Moskowitz's views on the education of low-achieving students. Changing the Course of Failure seems fatalistic-there is no hope. Stotsky argues, “The entire public school system is being held hostage to the test scores of students many if not most of whom, for a range of reasons, are not academically

James V. Shuls, is an associate professor and the department chair of Educator Preparation and Leadership at the University of Missouri-St. Louis. His most recent contribution, "Entertaining is Easy, Educating is Harder," appeared in AQ in winter 2020. 
inclined, do not attend school regularly, and/or do not like to read or write much.” She tells us, “Changes in the reading curriculum haven't made a difference.” (44) Neither have preschool programs, teacher professional development, home visits by teachers, smaller classes, increases in personnel, mathematics and reading coaches, changes in pedagogy, or standards.

Phelps says I accused Stotsky of "writing what she did not" and that I misread just one of her several suggested "possible long term solutions.” Stotsky herself criticized me for building my criticism around one "minor" point of her book. Here is the problem: this one possible solution-centralizing education policies for low achievers-is the premise that weaves itself throughout the entire book. Stotsky's book is 107 pages. Through the first ninety pages Stotsky argues that the hyper focus on low achieving students has had deleterious effects on the system as a whole, and particularly on high achieving students.

In all the sections leading up to the solutions, Stotsky tells us that nothing works. She then gives us five possible solutions. Her first solution is to stop requiring local schools to comply with federal laws for low achieving students, which I presume to include special needs students. Parents who want to can make their children "wards of the federal government." All other children can enroll in their local schools, with their locally determined educational policies. And just so we are clear, it is not as if her other solutions are particularly compelling: promote steady school attendance (Solution 2), stop any policies that are expressly intent on closing achievement gaps (Solution 3), provide more career/technical high schools (Solution 4), and require students to pass a citizenship test to earn a high school diploma (Solution 5).

I wasn't asked to review Stotsky's career or her other books. I was asked to review Changing the Course of Failure and Eva Moskowitz's memoir. From start to finish, the theme of Stotsky's book is that nothing works when it comes to improving the lot of the low achieving child. Dismissing me with a strawman argument or defending Stotsky's record or her other books does nothing to change the problematic message presented in this book. 